\title{
A Cross-country Study of the Effects of Institutional Ownership on Credit Ratings
}

\author{
AlHares, A. ${ }^{1} \&$ Ntim, C. G. ${ }^{1}$ \\ ${ }^{1}$ Huddersfield University, United Kingdom \\ Correspondence: AlHares, A., Huddersfield University, United Kingdom. E-mail: aws.alhares@hud.ac.uk
}

Received: June 4, 2017

Accepted: July 5, 2017

Online Published: July 18, 2017

doi:10.5539/ijbm.v12n8p80

URL: https://doi.org/10.5539/ijbm.v12n8p80

\begin{abstract}
A considerable number of studies have examined the relationship between corporate governance (CG) structures and corporate performance (e.g., Yermack, 1996; Gompers et al., 2003; Beiner et al., 2006; Renders et al., 2010; Ntim et al., 2012; Kumar \& Zattoni 2013; Griffin, et al., 2014). In contrast, despite its importance as demonstrated by the recent financial crisis, studies examining why and how a corporation's CG mechanisms might influence its credit ratings are rare (e.g., Switzer and Wang, 2013;Matthies, 2013; Tran, 2014). This research, therefore, seeks to contribute to the extant literature by exploring the effects of (CG) mechanisms on corporate credit ratings. Specifically, using a sample of 200 firms from 10 OECD countries over ten years covering the pre- and post-2007/08 global financial crisis period from Anglo American (i.e., Australia, Canada, Ireland, UK, and US) and Continental European (i.e., France, Germany, Italy, Japan and Spain) traditions and employing a total of 200 listed companies, this paper hopes to achieve a number of objectives. First, the paper attempted to assess the levels of compliance with, and disclosure of, CG principles contained in the 2004 OECD CG Code in firms from two different traditions: Anglo America and Continental Europe. Second, the paper sought to investigate the relationship between CG mechanisms and credit ratings. These relationships will be explored by employing firm-level CG mechanisms (ownership structures measured by Institutional Ownership) by accounting for firm-level control variables (e.g., firm size, growth, profitability, and leverage) based on a multi-theoretical framework that incorporates insights from agency and legitimacy theories. The findings revealed that there was a strong negative relationship between institutional ownership and credit ratings. From the descriptive analysis, it was shown that institutional owners did not have a very high credit rating. When the control variables were assessed, it was shown that they had a negative influence on the credit ratings with sales growth and leverage and positive significant relationship with firm size, corruption index, power distance and Anglo American countries.
\end{abstract}

Keywords: corporate governance, credit ratings, anglo-american tradition, continental european tradition, OECD Countries

\section{Introduction}

This study seeks to extend, as well as contribute to, the extant literature by consequently investigating the association between Institutional ownership and credit rating, using a sample of 200 companies from 10 OECD countries from Anglo-American and Continental European traditions over the 2010 to 2014 period and relying on a multi-theoretical framework.

The subject of corporate governance has captured the attention of world organisations with the publication of the OECD's first Principles of Corporate Governance in 1999 and the second Principles of Corporate Governance five years later (OECD, 2004). The importance of corporate governance became prominent with the recognition that management had to be held accountable for the functioning of their organisations, and this was evident from the many corporate scandals and failures that had taken place in the United States, the United Kingdom, and other European economies (Krenn, 2014).

The adoption of these Principles and their adaptation to various countries, ownership styles, and economic situations has contributed to corporate governance (CG) being considered a mark of success for organisations the world over (Krenn, 2014). But it must also be considered that there are various factors that affect how CG is carried out among countries, including the nature of the countries' economies, their legal systems, the governance systems established, the accounting systems used, and the protection afforded shareholders and other 
stakeholders.

As Radebaugh et al. (2006) maintain, there are corporate governance mechanisms that are under the control of the organisations and are known as internal controls, while there are governance mechanisms that are not under the control of the organisations, but are external factors characteristic of the particular countries, including, as stated above, the unique legal systems, specific economies, and unique ways countries have of doing business (Radebaugh et al., 2006).

However, despite the differences among countries, CG is considered a means of providing accountability that organisations are protecting the interests of their stakeholders, monitoring management's behaviour, while, at the same time, seeking to maximise their performance (Krenn, 2014).

This study is motivated by a number of things. First, while a number of studies have examined the association between general corporate governance and performance (e.g. Beasley, 1996; Hansson et al., 2011; Letza et al., 2004), the evidence relating to the impact of corporate governance on credit rating is rare (Tran, 2014). Similarly, the limited evidence on the impact of corporate governance mechanisms on credit rating has mainly been conducted within a single country rather a cross-country context (Ashbaugh-Skaife et al., 2004). Arguably, this limits the generalisability of the results.

Second, since OECD countries differ in the corporate governance structures they use (OECD, 2014), and since countries differ in the amount of transparency they provide to their shareholders (Ashbaugh-Skaife et al., 2004), rational investors without adequate information may consider that there would be additional costs that the company would have to undertake, which would effectively raise the cost of equity capital (Tran, 2014). This study intends to show investors what to look for when making decisions about investing in firms in different countries.

Third, recognising the importance of legal and financial institutions in determining governance mechanisms (Shleifer and Vishny, 1997), and the role of government regulations in influencing stock exchange rules and takeovers, this study aims to show the impact of legal, financial and other country characteristics on corporate governance and its influence on credit rating.

Fourth, the study will perform a comparative analysis of two different traditions: the first is a group of Anglo-American countries, including listed companies from the US, Canada, the UK, Australia and Ireland. The second is the Continental European or traditional countries, including listed companies from Germany, France, Italy, Spain and Japan. The purpose of this comparative study is to look at the impact of regional differences on different arrangements of corporate governance and ownership structures. Moreover, this study identifies and compares existing corporate governance codes in those ten countries. This study aims to extend the knowledge on the difference between the two traditions that are represented in the OECD, and how these are accommodated within the OECD Principles of Governance.

Accordingly, this study aims to extend, as well as contribute to, the current literature by applying the multi-theoretical framework focusing on agency and legitimacy theory. Agency theory is based on the arrangement in modern corporations, where there is separation of the role of owner and manager (Abdullah and Valentine, 2009). It is assumed that there is a conflict between owners and managers, where managers seek their own self-interest at the expense of the interests of the owners (Abdullah and Valentine, 2009). With this underlying conflict in the relationship between owners and managers, CG plays an important role in striving to address agency problems.

According to Lai and Chen (2014), studies carried out to examine the performance of organisations using agency theory sometimes come out with different findings. Some studies see CG as contributing to outstanding performance of companies, but on the other hand, there are some studies which do not show similar performance (Lai and Chen, 2014). The discrepancy may be based on the different stakeholders whose interests are being highlighted (Lai and Chen, 2014). In other words, using agency theory, the owners and managers are seen as having different interests (Abdullah and Valentine, 2009), and therefore performance from the perspectives of different owners and managers would very likely be assessed differently. Decisions that managers make would therefore be influenced by their own interests, except where CG ensures that the interests of the shareholders are given particular attention, or where managers are given incentives to ensure that the interests of the shareholders are protected.

It is for this reason that the organisations that have good corporate governance systems in place are organisations that are considered to be the best organisations in which to invest (Honore et al., 2015).

Legitimacy theory is based on examining whether the organisation meets the expectations of society. In other 
words, organisations declare their value systems, and legitimacy theory examines whether the values espoused by the organisation are congruent with the values of society. However, as pointed out, this theory does not outline specific means for bringing about congruency between an organisation's value system and that of the society in which it operates (Chen \& Roberts, 2010). Deegan and Bloomquist (2006) explain that organisations strive to show that there is congruence between the social values that they hold or try to display and the social values that are established in their society, using the Australian mineral industry and the World Wide Fund to illustrate this. Organisations try to legitimise themselves by showing that they are socially responsible.

In describing legitimacy theory, Chen and Roberts (2010) identify institutional legitimacy and strategy legitimacy. The former, which also takes in institutional theory, is based on the organisation conforming "to the established patterns of other similar social institutions" (p. 653). That is, the organisation gains legitimacy because it acts like similar organisations. But strategic legitimacy is achieved in terms of resource dependency theory and stakeholder theory. In terms of resource dependency theory, legitimacy is achieved in how the organisation is able to gain "access to relevant resources" (Chen \& Roberts, 2010, p. 653). In terms of stakeholder theory, legitimacy is achieved when an organisation is able to "balance the conflicting demands of various stakeholders" (Chen \& Roberts, 2010, p. 653).

Credit rating is another important concept that is critical to firm performance. Understanding how corporate governance mechanisms can influence credit rating requires an understanding of how credit ratings work. A credit rating is an opinion expressed by credit rating agencies as to a company's ability to meet its financial obligations (Standard \& Poor's, 2002). Credit rating is therefore based on how creditworthy the crediting rating agency thinks the firm is (Standard \& Poor's, 2002). On deciding the creditworthiness of a company, credit rating agencies examine its corporate governance structure. If the governance structure is weak, then the credit rating agencies would very likely see the firm's financial position as poor and stakeholders in the company as vulnerable to possible losses (Fitch Ratings, 2004). The credit rating agencies, based on this observation, would therefore give the company a poor credit rating (Fitch Ratings, 2004). Such a credit rating would alert investors and would-be investors that a particular firm has high risk levels; while some investors or lenders would see this as an opportunity, they may demand premium rates in order to take on such risk.

In deciding the credit rating of a company, credit rating agencies will take three major categories into consideration. The first is the financial ratios and other financial data of the company. Next, credit rating agencies will examine the corporate governance mechanisms. Third, these agencies would also take into consideration the economic conditions in which the company operates. National GDP growth will influence the credit ratings of companies in the particular country (Ashbaugh-Skaife et al., 2006).

It is also expected that the factors that influence CG would also influence Credit Rating in organisations. Two important questions that would be addressed in this paper are: How does CG drive Credit Rating and how does ownership structure moderate the assessment of Credit Rating? The objective of this paper is to see how CG plays a role in the decisions to promote Credit Rating in organisations, how the different types of ownership would either promote or discourage Credit Rating and how management makes decisions regarding Credit Rating.

This paper looks specifically at 10 countries, namely, the United States, Ireland, UK, Australia, Canada, France, Germany, Spain, Italy, and Japan, with the aim of examining corporations in each of these countries. These countries are drawn from the Anglo-American or Shareholding corporate governance model and from the Continental European or Stakeholding corporate governance model.

The Anglo-American model takes the shareholding perspective, or the belief that the directors of companies have as their fiduciary duty the maximisation of shareholder value. The major shareholders are to be seen as the privileged group in a company, because they are the ones that take the greatest risks, and so must be seen as the major owners of the companies (Gamble \& Kelly, 2001). The Continental European or stakeholding corporate governance model has several unique characteristics. One of these is the emphasis on maximisation of stakeholder interest, which includes employees and other stakeholders, where investment is carried out on a long term basis as opposed the short term is that characterises investment in the United States and the U.K. (Aguilera \& Jackson, 2010). In fact, according to these authors, the stakeholder approach as seen in the case of Germany as well as in Japan is characterised by "patient capital" when compared to the "short-termism" in investment observed in the United States and the U.K. (Aguilera \& Jackson, 2010, p. 553). Another characteristic of the European or Continental stakeholding model is the "team production" model as an alternative to the principal-agent approach, which suggests that the corporation consists of many stakeholders who jointly give control over their resources to a board of directors (Aguilera \& Jackson, 2010, p. 553). It is also a characteristic 
of the stakeholding model to have greater voice of stakeholders.

With the United Kingdom and the United States being a very strong influence with respect to the corporate governance codes, and with the OECD being greatly influenced in its 2004 Principles of Corporate Governance by the United Kingdom and the United States, the vast majority of codes that have developed within the past few years have used the Anglo-American governance style of good governance (Krenn, 2014). The OECD has insisted that its Principles be the minimum governance principles to be used, although nations could have more stringent governance principles.

What became apparent was that the OECD countries were different in terms of their legal framework, accounting systems, and culture. Nevertheless, they realised the importance of finding ways of promoting corporate governance. There were really two main corporate governance systems or models among OECD countries, which are commonplace and that oppose each other: the shareholding model and the stakeholder model (Sternberg, 1997; Weimer \& Pape, 1999; Vinten, 2001; Letza, Sun \& Kirkbride, 2004). These two models are based on shareholding and stakeholding theories. For example, the U.K., U.S., Canada, Ireland, and Australia were based on the shareholding model, while France, Germany, Spain, Italy and Japan followed the stakeholding model.

Among the countries that make up the global economy, there are two different legal systems, namely, the Anglo-Saxon common law system and the continental civil law system. The Anglo-Saxon, or Anglo-American, common law system is considered the superior legal system for accommodating corporate governance (La Porta et al., 2002). The Civil law is generally associated with European countries, and was a system of law that was codified and based on Roman law. This system was practiced throughout Europe, where "the role of local custom as a source of law became increasingly important" (University of California, Berkeley, p. 2). Civil law was classified as an "insider model" and had unique characteristics, such as heavy bank financing, little legal protection for minority shareholders, concentrated ownership, weak disclosure, stakeholders playing a central role in owning and managing corporations, and corporations having very little freedom to carry out mergers or acquisitions (Djankov, Lopez, La Porta \& Shleifer, 2008). As Aguilera and Cuervo-Cazurra (2008) point out, the difference between these two legal systems in terms of corporate governance is that while civil law uses statutes and codes to make legal rulings, common law uses precedents and case law to seek out equity.

Culture plays an important part in the business operations of a company and in its corporate governance. Organisations and their management are heavily dependent on the cultural practices that take place in a country. This explains why the concept of Western culture and its universal modern management methods are no longer considered a reality. As Hofstede (1984) points out, this is because although France, Germany, Sweden and the U.K. are all seen as "Western", their types of management differ because of cultural factors (p. 81).

The rationale for taking this position is that it is the specific cultural practices and values that determine the goals of a country and the economic and technical resources that would be used to achieve the goals (Hofstede, 1984, $p$. 81). Culture is based on how people behave in their particular settings. This being the case, it can be clearly seen that the activities that take place in different countries must therefore be determined by the culture of the country. Some of the cultural values that influence how people behave, and which seriously impact how management works in different countries, are individualism versus collectivism, large versus small power distance, strong versus weak uncertainty avoidance, and masculinity versus femininity (Hofstede, 1984).

The paper is organised as follows. The next section briefly considers CG and risk reforms in the OECD. The following sections present the theoretical framework, review the empirical literature and develop the hypotheses, outline the research methodology and discuss the findings of the paper. The concluding remarks of the paper are provided in the final section.

\section{Corporate Governance and Risk Reforms in the OECD}

With financial failures being rampant in the 1990s, and with specific measures undertaken in the form of the Cadbury Committee in 1992 in the UK and with the established as a result of this committee, the OECD undertook the development of the first Principles of Corporate Governance, intended to set guidelines that OECD countries could follow to improve their governance (Kirkpatrick, 2009). The main focus of the Cadbury Committee was protecting shareholder interests, with recommendations to establish internal committees that were aimed at undertaking to "link executive rewards more closely to performance" (Weir and Laing, 2000, p. 268). The passage of the first Principles of Corporate Governance (1999) was followed by the second Principles of Corporate Governance (2004), where changes were introduced to make CG more applicable over a wide range of companies. 
In order to deal with Credit Rating, OECD (2004) made some risk reform recommendations. The second Principles of Corporate Governance (2004) were said to focus on three main areas. According to Kirkpatrick (2004), the three main areas were in "“"ensuring the basis for an effective corporate governance framework which was before largely implicit," "the effective exercise of ownership" and "dealing with conflicts of interest" (Kirkpatrick, 2004, p. 2). The OECD (2004) recommended that there should be a good governance structure in place to provide oversight. However, the areas of ownership and conflict of interests were areas that became even more critical for CG.

In making reforms to the 1999 Principals of Corporate Governance, the OECD held consultations with OECD and non-OECD members through the work of the OECD Steering Group on Corporate Governance in the period between 2002 and 2003. It also drew heavily on the U.K. and U.S. Sarbanes-Oxley Act. Following this consultation, the OECD introduced some reforms in order to make the Principles more applicable to more groups. As Kirkpatrick (2004) points out, the Principles were "advanced in three main areas". These areas were in "ensuring the basis for an effective corporate governance framework which was before largely implicit," "the effective exercise of ownership" and "dealing with conflicts of interest" (Kirkpatrick, 2004, p. 2).

Reform was also introduced in the Principles with respect to ownership. Whereas the previous Principles dealt primarily with shareholders, the new Principles took into concern the fact that there can be lack of effective ownership among OECD countries. The new Principles therefore put more attention to voting rights and that more attention should be given to the role of ownership and that the importance of board and remuneration for key executives have been seen as new areas where attention needed to be focused. Another area where reform was forthcoming was in the area of conflict of interests. In recent years, as Kirkpatrick explains, it was noted that conflicts of interest were quite widespread and it was seen as having the potential to cause harm to shareholders, investors and other stakeholders. This led to the OECD looking more closely at the different shareholders, and requiring that there should be more disclosure. This reform was to have a tremendous impact on how owners are involved in corporate governance. Attention was also given to institutional investors, with the requirement that acting in a fiduciary capacity they should disclose their own corporate governance policies, and how they decide on using their voting rights (Kirkpatrick, 2004, p. 3).

In terms of ownership, the new Principles recognised that there were different types of corporate ownerships among the various countries and so recommended measures that would allow companies in these various countries to institute protections of organisations' wealth. The OECD (2004) called attention to voting rights, and to the role of ownership, importance of the board of directors, and the remuneration of directors (Kirkpatrick, 2004). This meant that more emphasis was placed on the different types of shareholders, investors, and other stakeholders, and the need for more disclosure, so that there was greater knowledge about the workings of the organisations.

Corporate governance mechanisms were therefore recommended to ensure that these three main areas of reform were therefore implemented in organisations. But the OECD (2004) Principles also recognised that there could not be one set of rules to which all nations had to adhere. Therefore, the OECD (2004) pointed out that the Principles were to serve as 'reference point' that corporations were to use to bring their operations into compliance with good corporate governance. The OECD (2004) therefore pointed out that it was not only the companies but the countries that had a responsibility to ensure that good corporate governance was established.

"To remain competitive in a changing world, corporations must innovate and adapt their corporate governance practice so that they can meet new demands and grasp new opportunities. Similarly, governments have an important responsibility for shaping an effective regulatory framework that provides for sufficient flexibility to allow markets to function effectively and to respond to expectations of shareholders and other stakeholders" (OECD, 2004).

The OECD (2004) therefore outlined principles that companies and countries could adapt that would improve their corporate governance, and make their operations more appealing to investors.

OECD Principles (2004) called for a strong governance framework to improve credit rating. There was to be a governance framework with clearly defined responsibilities, among supervisory, regulatory and enforcement authorities, and these authorities were to carry out their functions in a transparent and efficient manner (OECD, 2004). It is within this framework that the rights of shareholders and key ownership functions are to be clearly outlined.

The rights of shareholders that have to be laid out are rights of ownership, rights to participate in decisions regarding changes taking place in the organisations, rights to be informed about shareholder matters, their voting rights on these matters, rights of certain shareholders to have greater control based on having much greater 
investment in the organisations, rights of all shareholders, including institutional investors, to exercise ownership, rights of all shareholders to be able to consult with each other, except in cases where such consultation could be seen as abuse of rights (OECD, 2004).

Therefore, the mechanisms that were recommended for ownership rights are that these rights should be registered, shareholders should have the right to transfer or convey their share, be able to participate in shareholders' meetings, and should have voting rights, and have the right to elect and remove members of the board (OECD, 2004).

In protecting the rights of the shareholders, the board were to have the responsibility of monitoring the performance of the company and the remuneration of key executives. The rationale was that if there was not a strict oversight that managers would look after their own well-being at the detriment to shareholders (OECD, 2004). This was in keeping with agency theory.

Therefore, in this study, in order to examine how CG drives Credit Ratings and how ownership structure moderates the assessment of Credit Ratings, it would be necessary to see what CG mechanisms are in place to support Credit Ratings in the various companies, and to see how the ownership styles across countries and across companies make a difference in whether or not Credit Ratings is encouraged or discouraged.

The sample firms used in this paper are drawn from companies that are listed in the World's Biggest Public Companies listing, FORBES Global 2000 Leading Companies (Forbes, 2000). The sample is made up of 200 companies that were taken from 10 or $29.4 \%$ of the 34 OECD countries. The 200 companies have been selected both from the Anglo American tradition, which include companies from the five countries of Australia, Canada, Ireland, UK and US, and from the Continental European tradition, which includes companies from the 5 countries of France, Germany, Italy, Japan and Spain. These companies are drawn from 10 industries, namely, basic materials, consumer goods, consumer services, financials, health care, industrials, oil and gas, technology, telecommunications, and utilities. The period that was focused on was from 2010 to 2014, resulting in 1,000 firm-year observations. The study looked at how corporate governance mechanisms impact Credit Ratings, in these firms in the various industries mentioned above.

\section{Theoretical Framework}

\subsection{Agency Theory-Manager-Shareholder Conflicts}

It is expected that when agency theory is applied to corporate governance and credit rating, credit rating would be positive in the presence of strong governance. Would-be lenders are impressed with good corporate governance systems, as agency problems which arise between ownership and control, from conflicts of interest between controlling and non-controlling shareholders, and from self-interested managers, would be greatly reduced or eliminated.

Investors are also concerned with maximising their investments, and they choose companies with a good credit rating. A good credit rating is based to a great degree on the absence of risk, and, as noted above, where there is much conflict in the principal-agent relationship, there is much systemic risk (Garmaise \& Liu, 2005). It would follow that a company with a good corporate governance structure and with appropriate mechanisms for reducing this conflict, would also be a company that would have good credit rating. Governments, investors, banks, and brokers all use credit ratings to determine creditworthiness. The corporate governance structure of an organisation can therefore indicate to an investor whether a company would make a good investment choice (Ahmad, Rashmi, Bakshi, \& Saha, 2009).

It was noted that where there is good corporate governance and a separation of the roles of CEO and chair of the board, organisations are more likely to be viewed more positively, as the detrimental effect of this duality is removed. In many organisations, the removal of this duality brings about better corporate governance. It is expected that credit ratings are more positive than where there is better corporate governance (Elbannan, 2009; Jiraporn, Kim, Kim, Kitsabunnarat, 2012).

Credit ratings are said to affect the ability of an organisation to borrow and so organisations that have poor governance and that are highly leveraged would very likely have low credit rating. As Elbannan (2009) points out, organisations that have poor governance are more likely to have poor credit ratings. According to agency theory, if there is good corporate governance, then there is likely to be good credit ratings for the firm.

\subsection{Legitimacy Theory}

An organisation that loses its legitimacy runs the risk of having lower credit ratings. This would happen because 
it would not behave in socially expected ways, would be unable to attract necessary resources and so would be unable to carry out its operations in a manner that allows it to achieve expected levels of performance. If an organisation is seen as not meeting and balancing the needs of its stakeholders, it would earn a reputation for having weak internal control. As mentioned before, "corporate governance strength is positively related to internal control quality" (Elbannan, 2009, p. 127), but corporate governance is also associated with better credit ratings (Elbannan, 2009).

Good corporate governance is seen as important to maintaining good credit ratings. Organisations that show themselves as having legitimacy behave as expected, are good corporate citizens and have a reputation for meeting the needs of all their stakeholders. As mentioned above, these organisations can balance stakeholders' needs, showing that they are considered legitimate not only by shareholders, but also by employees, customers and other stakeholders. For example, this type of organisation is not likely to have labour disputes which could present a major operational risk.

These considerations make legitimacy theory important in considering credit ratings; an organisation that is able to gain the support of its stakeholders and that can live up to its reputation of being a good corporate citizen will face fewer risks and enjoy good ratings from investors, credit agencies and other users of the organisation.

\section{Institutional Ownership and Credit Ratings: Literature Review and Hypotheses Development}

In this section, ownership structure is discussed in terms of credit ratings. The objective is to see how institutional ownership is implicated in credit ratings. Ownership structure is the element used to represent governance structure. Conflicts have often been induced in large publicly owned firms between the interests of stockholders and those of professional managers (Chen et al., 2009; Tran 2014), based on agency theory. These conflicts emerge as stockholders want to maximise the profit of the firm over the long term while also safeguarding their investments. On the other hand, managers want to ensure that they are managing the firm's business according to objectives so as to ensure job security and prestige of the firm, but they also want to increase their personal wealth. These two goals are usually at odds as agency theory explains, because of separation of ownership and control in these firms. It is the difference between the objectives of managers and those of stockholders that lead to conflicts about the strategic direction that the organisation should take (Hail and Leuz 2006).

Institutional owners and outside board members have been amply discussed in terms of their roles in corporate governance. While many research studies have shown that institutional owners and external directors monitor the actions of management and take measures to protect shareholders, other research studies have failed to show any effect of these corporate governance mechanisms on corporate performance.

Bhojraj and Sengupta (2003) conducted a study with a sample of 1,005 industrial bond issues collected from the Warga Fixed Income Database from 1991 to 1996. They found that firms with more institutional ownership had higher bond ratings and lower bond yields (Bhojraj and Sengupta, 2003). Bhojraj and Sengupta (2003) discovered that when institutional ownership becomes concentrated, it leads to lower ratings and higher yields for firms. Further, they found that firms with more outside directors on the board showed higher ratings and lower bond yields (Bhojraj and Sengupta, 2003).

Bhojraj and Sengupta (2003) were consistent with their findings that the monitoring of management by institutional owners and outside directors contributes to a reduction in management opportunism and an improvement in firm value. Their findings are also shown to be consistent with an alternative explanation. The argument can also be made that there is a positive association between institutional ownership and bond ratings, and a negative association between institutional ownership and bond yields. This association comes from institutions' preference for investing in higher rated bonds. Controlling for the potential change that institutional owners make based on the relationship between institutional ownership and bond yields and ratings, Bhojraj and Sengupta (2003) apply a simultaneous equations approach. In this approach, they show that institutional ownership influences bond yields and ratings, but is also influenced by bond yields and ratings. Consequently, these findings also suggest that institutions invest more in companies that have higher and lower bond ratings and yields respectively. However, regardless of the explanation, institutional ownership continues to be statistically significant in determining bond ratings and yields.

Given the institutional ownership evidence, both the null and alternate hypotheses are tested. The respective null hypothesis to be tested in this study is:

H1: There is no statistically significant relationship between institutional ownership and credit ratings. 


\section{Research Design}

\subsection{Data Collection Procedure}

\subsubsection{Corporate Governance Data}

This study uses the OECD Corporate Governance Principles (2004) to investigate the quality of corporate governance practices in the companies used in the sample. In examining the effect of corporate governance on credit ratings. The annual reports were obtained from the Perfect Information Database and companies' website. When annual reports were not readily available, and when data was not available on in the Perfect Information Database, the company was contacted directly through phone call or email, or through the companies' website.

\subsubsection{Credit Ratings Data}

This section deals with credit rating data and is not as straightforward as finding this information in one place. It is necessary to look at different ways in which credit rating is assessed, including the use of credit agencies.

The measurement of credit ratings can be carried out by examining the default frequencies with which companies in the same classification are denied credit, and by investigating the changes in credit rating that take place as prices and returns on stocks and bonds are adjusted (Jorion \& Zhang, 2007). Estimations of default probabilities for individual rating categories can therefore be made on the basis of default frequencies. However, when agencies assign credit ratings, they define those ratings in terms of the quality of credit the individual firm has, and do not use a specific default probability for the individual rating categories (Matthies, 2013). Consequently, we decided to assign credit ratings to firms based on Standard \& Poor's compilations of long-term issuer credit ratings. Standard \& Poor's ratings range from best to worst as follows: AAA, AA+, AA, AA-, A+, $\mathrm{A}-, \mathrm{BBB}+, \mathrm{BBB}, \mathrm{BBB}-, \mathrm{BB}+, \mathrm{BB}, \mathrm{BB}-, \mathrm{B}+, \mathrm{B}, \mathrm{B}-, \mathrm{CCC}+, \mathrm{CCC}, \mathrm{CCC}-, \mathrm{CC}, \mathrm{C}, \mathrm{RD}, \mathrm{SD}$ and $\mathrm{D}$. It is important to note that rating scales are ordinal, and not cardinal, meaning that credit quality is shown to increase as the categories decline down the scale.

\subsubsection{Firm Level Data}

The firm-level data include firm size, measured by log of total assets, sales growth, audit committee number, corporate governance committee number, leverage and capital gain yield, as well as year dummies and country dummies.

\subsubsection{Country Level Data}

This section considers factors in which companies differ, and notes the potential for different outcomes for companies based on these different factors. The information provided in this study is drawn from country level. This includes stock market capitalisation, corruption index, inflation, GDP per capita, Hofstede's culture variables (masculinity and power distance), population and exchange rate. These include the country's legal system, whether common law or civil law. Countries with common law systems tend to have better protection for shareholders than countries with civil law systems. The accounting system used, whether based on international or local accounting standards, is also important, as different systems have different reporting requirements and notions of acceptable practice. The corporate governance system used, whether Anglo-American or Continental-European, also has different requirements and different protections for shareholders. A country's GDP gives an indication of the prosperity and size of the economy, and the level of investment in the economy. The level of corruption in the country, its inflation rate and the treatment of shareholders' rights are all factors that are significant to investors, affecting the amount of caution that an investor should exercise when investing in a particular economy. Population size, culture and cultural variables are important factors that shed light on an economy. This information is accessed from the World Bank website and other global sources of financial information on countries, as well as from the World Federation of Exchanges. Hofstede's cultural variables also help identify the manner in which companies in particular countries approach business dealings.

\subsection{Sample}

The sampled firms used in this paper are drawn from companies that are listed in the World's Biggest Public Companies listing, FORBES Global 2000 Leading Companies (Forbes, 2000). The sample is made up of 200 companies that were taken from ten, or $29.4 \%$, of the 34 OECD countries. The 200 companies represent both the Anglo-American tradition, including companies from Australia, Canada, Ireland, the UK and the US, and the Continental European tradition, which includes companies from France, Germany, Italy, Japan and Spain. These companies are drawn from ten industries, namely, basic materials, consumer goods, consumer services, financials, health care, industrials, oil and gas, technology, telecommunications and utilities, as shown in Table 1 below. The period of focus is 2010 to 2014 , resulting in 1,000 firm-year observations. The study looks at how 
corporate governance mechanisms impact the credit rating of these firms in the various industries mentioned above.

The rationale for selecting countries from both traditions, from these various industries, and for these years is to show how companies from these different traditions and industries performed after the financial crisis. This information is ascertained using secondary data obtained from the websites and financial reports of the companies. The sample was stratified, drawn from large, medium and low firms based on their total assets and sales as part of the FORBES 2000 information provided.

The information used examines corporate governance mechanisms with the aim of showing how these mechanisms affected the financial characteristics of the firms. The study also shows the difference between the traditions with respect to the governance mechanisms used, and how this has implications for the firms' performance during the period of study.

An inclusion criterion of the companies taking part in the study was that they had experienced the global financial crisis, and data was available for a period after this event. An exclusion criterion was that any firms that had independent variables missing that were necessary for the analysis would be eliminated from the sample. Utility firms and firms from the financial industry were also excluded, as these industries have a different capital structure and are heavily regulated, which is likely to impact their governance structures differently than firms in other industries (Yermack, 1996; Weir et al., 2002; Cheng, 2008).

Two French companies were excluded because their annual reports were in French only they were replaced with other companies from the sample. Some countries, such as Ireland, Italy and Spain, had fewer than 20 firms in FORBES 2000 after excluding utility and financial companies. In order to compensate for this, firms that were listed on their stock markets were used.

Table 1. Summary of the sample selection procedure

Panel A: Industrial Composition of all listed firms on the FORBES 2000 as at 31/12/2014

\begin{tabular}{|c|c|c|c|c|c|c|c|c|c|c|c|c|c|c|c|c|c|c|c|c|}
\hline & USA & $\%$ & Canada & $\%$ & UK & $\%$ & Australia & $\%$ & Ireland & $\%$ & Germany & $\%$ & France & $\%$ & Italy & $\%$ & Japan & $\%$ & Spain & $\%$ \\
\hline Financials & 64 & 11.4 & 14 & 26.9 & 24 & 25.3 & 11 & 32.4 & 5 & 26.3 & 11 & 20.4 & 9 & 14.8 & 17 & 56.7 & 57 & 26.0 & 10 & 37.0 \\
\hline Industrials & 136 & 24.2 & 3 & 5.8 & 30 & 31.6 & 3 & 8.8 & 3 & 15.8 & 18 & 33.3 & 13 & 21.3 & 3 & 10.0 & 54 & 24.7 & 4 & 14.8 \\
\hline Basic Materials & 22 & 3.9 & 8 & 15.4 & 5 & 5.3 & 1 & 2.9 & 2 & 10.5 & 1 & 1.9 & 5 & 8.2 & 1 & 3.3 & 24 & 11.0 & 0 & 0 \\
\hline Consumer Services & 96 & 17.1 & 5 & 9.6 & 17 & 17.9 & 6 & 17.6 & 1 & 5.3 & 5 & 9.3 & 8 & 13.1 & 2 & 6.7 & 19 & 8.7 & 4 & 14.8 \\
\hline Consumer Goods & 47 & 8.3 & 5 & 9.6 & 6 & 6.3 & 3 & 8.8 & 2 & 10.5 & 8 & 14.8 & 11 & 18.0 & 1 & 3.3 & 23 & 10.5 & 1 & 3.7 \\
\hline Technology & 63 & 11.2 & 1 & 1.9 & 0 & 0 & 3 & 8.8 & 2 & 10.5 & 2 & 3.7 & 4 & 6.6 & 0 & 0.0 & 15 & 6.8 & 0 & 0 \\
\hline Health Care & 49 & 8.7 & 1 & 1.9 & 3 & 3.2 & 2 & 5.9 & 4 & 21.1 & 3 & 5.6 & 2 & 3.3 & 0 & 0.0 & 8 & 3.7 & 1 & 3.7 \\
\hline Telecommunications & 10 & 1.8 & 4 & 7.7 & 3 & 3.2 & 1 & 2.9 & 0 & 0 & 3 & 5.6 & 3 & 4.9 & 0 & 0.0 & 3 & 1.4 & 2 & 7.4 \\
\hline Oil and Gas & 43 & 7.6 & 10 & 19.2 & 2 & 2.1 & 2 & 5.9 & 0 & 0 & 0 & 0.0 & 2 & 3.3 & 2 & 6.7 & 8 & 3.7 & 1 & 3.7 \\
\hline Utilities & 33 & 5.9 & 1 & 1.9 & 5 & 5.3 & 2 & 5.9 & 0 & 0 & 3 & 5.6 & 4 & 6.6 & 4 & 13.3 & 8 & 3.7 & 4 & 14.8 \\
\hline Total Population & $\underline{563}$ & & $\underline{52}$ & & $\underline{95}$ & & $\underline{34}$ & & $\underline{19}$ & & $\underline{54}$ & & $\underline{61}$ & & $\underline{30}$ & & $\underline{219}$ & & $\underline{27}$ & \\
\hline Less: Financials \& & 64 & & 14 & & 24 & & 11 & & 5 & & 11 & & 9 & & 17 & & 57 & & 10 & \\
\hline Utilities & $\underline{33}$ & & 1 & & $\underline{5}$ & & $\underline{2}$ & & $\underline{0}$ & & $\underline{3}$ & & $\underline{4}$ & & 4 & & $\underline{8}$ & & 4 & \\
\hline Total Sampled Firm & 466 & 82.7 & 37 & 71.2 & 66 & 69.4 & 21 & 61.7 & 14 & 73.7 & 40 & 74 & 48 & 78.6 & 9 & 30 & 154 & 70.3 & 13 & 48.2 \\
\hline
\end{tabular}

Panel B: The Final 200 Stratified Sampled Firms

\begin{tabular}{|c|c|c|c|c|c|c|c|c|c|c|c|c|c|c|c|c|c|c|c|c|}
\hline & USA & $\%$ & Canada & $\%$ & UK & $\%$ & Australia & $\%$ & Ireland & $\%$ & Germany & $\%$ & France & $\%$ & Italy & $\%$ & Japan & $\%$ & Spain & $\%$ \\
\hline Industrials & 136 & 24.2 & 3 & 5.8 & 30 & 31.6 & 3 & 8.8 & 3 & 15.8 & 18 & 33.3 & 13 & 21.3 & 3 & 10.0 & 54 & 24.7 & 4 & 14.8 \\
\hline Basic Materials & 22 & 3.9 & 8 & 15.4 & 5 & 5.3 & 1 & 2.9 & 2 & 10.5 & 1 & 1.9 & 5 & 8.2 & 1 & 3.3 & 24 & 11.0 & 0 & 0 \\
\hline Consumer Services & 96 & 17.1 & 5 & 9.6 & 17 & 17.9 & 6 & 17.6 & 1 & 5.3 & 5 & 9.3 & 8 & 13.1 & 2 & 6.7 & 19 & 8.7 & 4 & 14.8 \\
\hline Consumer Goods & 47 & 8.3 & 5 & 9.6 & 6 & 6.3 & 3 & 8.8 & 2 & 10.5 & 8 & 14.8 & 11 & 18.0 & 1 & 3.3 & 23 & 10.5 & 1 & 3.7 \\
\hline Technology & 63 & 11.2 & 1 & 1.9 & 0 & 0 & 3 & 8.8 & 2 & 10.5 & 2 & 3.7 & 4 & 6.6 & 0 & 0.0 & 15 & 6.8 & 0 & 0 \\
\hline Health Care & 49 & 8.7 & 1 & 1.9 & 3 & 3.2 & 2 & 5.9 & 4 & 21.1 & 3 & 5.6 & 2 & 3.3 & 0 & 0.0 & 8 & 3.7 & 1 & 3.7 \\
\hline Telecommunications & 10 & 1.8 & 4 & 7.7 & 3 & 3.2 & 1 & 2.9 & 0 & 0 & 3 & 5.6 & 3 & 4.9 & 0 & 0.0 & 3 & 1.4 & 2 & 7.4 \\
\hline Oil and Gas & 43 & 7.6 & 10 & 19.2 & 2 & 2.1 & 2 & 5.9 & 0 & 0 & 0 & 0.0 & 2 & 3.3 & 2 & 6.7 & 8 & 3.7 & 1 & 3.7 \\
\hline Total Sample & 20 & & 20 & & 20 & & 20 & & 20 & & 20 & & 20 & & 20 & & 20 & & 20 & \\
\hline
\end{tabular}




\subsection{Variables Measurement and Regression Model}

Table 2 summarises all variables used in conducting the empirical study. Data on credit rating is taken from the long-term issuer credit ratings by Standard and Poor's. Going from highest to lowest, this agency agrees on the following broad ratings: premier, high grade, upper medium grade, lower medium, non-investment grade, speculative, highly speculative, substantial risks, extremely speculative, default imminent, and lastly, in default. Standard and Poor's agrees that a premier credit rating is reserved for companies with long-term AAA.

The independent variables that would be used is ownership structure measured by Institutional Ownership. The measurement of ownership structure is carried out on the basis of institutional ownership (IO), which is measured by the number of shares owned by institutional.

Lin and Shen (2015) note that ownership of family companies tends to have the opportunity to influence their credit ratings, because they have the possibility of showing greater earnings. However, as these researchers point out, while a family firm may be able to manipulate earnings, if family idiosyncratic risk is observed, this would lessen the company's credit rating (Lin and Shen, 2015).

Dasilas and Papasyriopoulos (2015) show that capital structure, credit rating and corporate governance are closely related in small as well as large Greek companies. Corporate governance and credit ratings were seen to significantly affect the structure of the organisations.

Table 2. Variables definition and measurement

\begin{tabular}{ll}
\hline Corporate governance (CG) variable \\
\hline IO & $\begin{array}{l}\text { Percentage of total number of ordinary shares held by institutional shareholders with at least 5\%, to the total number of ordinary } \\
\text { shares }\end{array}$ \\
CR & $\begin{array}{l}\text { Firm long-term credit rating obtained from Standard \& Poor's (S\&P's) ratings ranging from AAA (highest rating) to D (lowest } \\
\text { rating- debt in payment default). These ratings reflect S\&P's assessment of the creditworthiness of the debtor with respect to its } \\
\text { senior debt obligations. }\end{array}$ \\
Control variables \\
SG & The ratio of current year's sales minus previous year's sales, all divided by previous year's sales \\
FS & Natural logarithm of the book value of total assets \\
AC & Total number of Audit Committee \\
CGC & Total number of Corporate Governance Committee \\
LVG & The ratio of total debt to total assets \\
CGY & The rise in the stock price divided by the original price of the security \\
SMC & The market value of the shares outstanding \\
CORR IDX & The misuse of public power for private benefit \\
INF & The rate at which the general level of prices for goods and services is rising \\
GDPC & Gross domestic product (GDP) divided by number of people in the country \\
POP & People living in a country \\
POWD & The degree to which the less powerful members of a society accept and expect that power is distributed unequally \\
ANGL & A dummy variable for Anglo American countries (1), Continental countries (0) \\
CON & A dummy variable for each country: UK (DU UK)... US (DU US) \\
Y & A dummy variable for each year of the ten years from 2010-2014 2010 (DU 10), 2011 (DU11) ... 2014 (DU14) \\
\hline
\end{tabular}

Control variables that were thought to be able to influence Credit Rating were incorporated. For example, firm size was shown as a logarithm of the total assets in each year. Country information would be obtained from global sources, such as country statistics, and company information would be obtained from company websites as well as from annual reports. A valuation model and panel data from companies in the United States, Ireland, UK, Australia, Canada, France, Germany, Spain, Italy, and Japan will be used. This study set out to examine the how Institutional ownership influence Credit Rating and how country characteristics moderate the relationship between Credit Rating and firm value.

Ordinary least squares (OLS) regression would be used to test our hypothesis. The dependent variable in these regressions is the Credit Rating. Since it may be influenced by past performance, growth, ownership characteristics and corporate governance characteristics, among others, all of these variables are included in the regression analysis to control for confounding factors (Han et al., 2015). Year and industry dummies would be used in all regressions in order to control for the year and the industry. The correlation analysis would be carried 
out with all variables.

$$
C R_{i t}=\alpha_{0}+\beta_{3} I O_{i t}+\sum_{i=1}^{n} \beta_{i} F C O N T R O L S_{i t}+\sum_{i=1}^{n} \beta_{i} C C O N T R O L S_{i t}+\varepsilon_{i t}
$$

\section{Empirical Findings}

The empirical findings that would be presented here reveal that relationship between institutional ownership and credit ratings among the different countries that were sampled in this study. It was shown from the descriptive analysis and bivariate correlations, Pearson and Spearman correlatives and the regression analyses that there is a negative relationship between institutional ownership and credit ratings.

\subsection{Descriptive Analysis and Bivariate Correlations}

The institutional ownership figure represents the percentage of total number of ordinary shares held by institutional shareholders with at least $(5 \%)$, to the total number of ordinary shares. This mean is given as $(16.57 \%)$ and the median as $(12.74 \%)$, with standard deviation of $(11.92 \%)$, and minimum of $(5 \%)$ and maximum of $(100 \%)$. This represents a relative small portion of companies in which institutional ownership plays a part. The credit rating for Institutional ownership among the companies is (16.12), with the median being (16) and with the minimum being (9) and the maximum being (23). What this shows is that the credit rating for institutional owners was not very high. The standard deviation was (2.881).

Control variables in this study are considered to have an influence on credit rating among institutional owners and were therefore incorporated into the figures. For example, a look at sales growth reveals that while the mean is $(7.52 \%)$, the median is $(4.34 \%)$, with standard deviation being $(17.72 \%)$. While the minimum value is $(-43.14 \%)$, the maximum is $(238.65 \%)$, showing that there is a wide difference between companies with institutional owners in terms of credit rating and in terms of how sales growth affects credit ratings.

Table 3. Summary descriptive statistics of the independent and control variables

\begin{tabular}{|c|c|c|c|c|c|}
\hline Variables & Mean & Median & Std, Dev. & Min & Max \\
\hline \multicolumn{6}{|c|}{ Panel A: Independent (Corporate governance (CG)/ownership characteristics) variable } \\
\hline IO (\%) & .1657 & .1274 & .1192 & .05 & 1.0 \\
\hline \multicolumn{6}{|c|}{ Panel B:Dependent Variable (Credit Rating) } \\
\hline CRS\&P & 16.12 & 16 & 2.881 & 9 & 23 \\
\hline \multicolumn{6}{|c|}{ Panel C: Control variables } \\
\hline$S G$ & .0752 & .0434 & .1772 & -.4314 & 2.3865 \\
\hline$F S$ & 4.2724 & 4.2116 & .6170 & 2.4641 & 5.8757 \\
\hline$A C N O$ & 4.28 & 4.00 & 1.114 & 2 & 8 \\
\hline CGC NO & 3.75 & 4.00 & 1.328 & 1 & 9 \\
\hline$S M C$ & 6.2165 & 6.2505 & .5672 & 4.7808 & 7.4204 \\
\hline CORR IDX & 71.92 & 74 & 12.3 & 39 & 89 \\
\hline INFL & .0169 & .0175 & .01131 & -0.009 & .045 \\
\hline$P O P$ & $82,042,575.4$ & $62,051,376$ & $83,685,858.43$ & $4,560,155$ & $318,857,056$ \\
\hline$L V G$ & .6043 & .6151 & .1762 & .0257 & 1.2544 \\
\hline$A N G$ & .5 & .5 & .5 & 0 & 1 \\
\hline$G D P C$ & 45217.858 & 45736.95 & 8931.1789 & 28992.6 & 45217858 \\
\hline POWD & 44.2 & 39.5 & 11.853 & 28 & 68 \\
\hline
\end{tabular}

Notes: Variables are defined as follows:

Sales Growth (SG), Firm Size (FS), Audit Committee No. (AC), Corporate Governance Committee No. (CGC

NO), Leverage (LVG), Stock Market Capitalisation (SMC), Corruption Index (CORR IDX), Inflation (INFL),

GDP per Capita (GDPC), Population (POP), Power Distance (POWER D), Anglo American (ANG).

In considering control variables, one must consider that some of these variables are under the control of the organisation and these are seen as internal controls; however, there are variables that are not under the control of the organisation, although they also have an impact on the organisations (Radebaugh et al., 2006). This would be noted in the findings below.

Firm size is a logarithm of the book value of total assets, with the mean being (4.2324) and the median being (4.2116), with standard deviation of (.6170). While the mean is (2.4641) the maximum is (5.8757). This reveals 
that the firm size has a positive influence on credit rating. Large organisations can therefore be seen as having a greater impact on credit rating, for such organisations could be seen as having more resources than smaller companies that have very scarce resources.

The total number of audit committees and or corporate governance committees can also be seen as influencing credit ratings among institutional owners. The relationship is also seen as positive, with the mean and median for auditing committee number being (4.28) and (4.00), respectively, and that of the corporate governance committee number being (3.75) and (4.00), respectively. The minimum and maximum for Audit Committee number and Corporate Governance Committee number varying between (2) and (8) and (1) and (9), respectively. The presence of these committees is important in influencing credit ratings. In considering the presence of audit and corporate governance committees in organisations, one must take into consideration that separation between owner and manager is seen as an important requisite for good governance according to agency theory (Ashbaugh-Skaife et al., 2004). The reason for this is the fact that agency theory holds that there is a conflict of interest here, for managers are seen as looking after the interests of the shareholders in a company, while owners are really looking after their own interests. According to Abdullah and Valentine (2009), corporate governance could be compromised because of this conflict between managers and owners. In the case of institutional owners, research has shown that the findings have come out differently (Abdullah and Valentine, 2009). The different findings are based on studies looking at what happens in this context. According to Lai and Chen (2014), some studies shown that using agency theory, corporate governance gives rise to the interests of the stakeholders being good and the performance of the firm being good. On the other hand, these authors maintain that this was not the case (Lai and Chen, 2014). This has come about when showing that managers and owners have different interests.

Further, in looking at the relationship between general corporate governance and performances, Letza et al. (2004), Hansson et al. (2011), and Tran (2014) believe that there is very little evidence that corporate governance has an impact on credit rating, but the most of these studies have been carried out in single country context (Ashbaugh-Skaife et al., 2004). The finding on our study varies, and this may be based to some degree on the fact that this study was carried out in a cross-country context (Ashbaugh-Skaife et al., 2004).

Corruption Index shows that there was a high incidence among institutional ownership which affected credit rating, for while the mean was (71.92), the median was (74), with the minimum being (39) and the maximum being (89). The standard deviation was (12.3), showing that this index varies widely among companies with institutional owners. An explanation for this could be that the majority of the countries in which the corruption index was high demonstrated that it affected credit rating. Since these were also countries in the stakeholding tradition, the European model, the fact that institutional ownership was held by many founder families who made decisions primarily in their interests would also be supposed by owners making decisions for their interests (Aguilera and Cuervo-Cazurra, 2009).

It was also shown that credit rating was greatly affected by power distance with the mean being (44.2) and the median being (39.5), while the minimum was (28) and the maximum (68). What this shows is that in countries where there is power distance, institutional owners seem to have strong influence over credit rating (Aguilera and Cuervo-Cazurra, 2009). This influence is widely accepted in countries where power distance is a way of life. (Hofstede, 1984). Inflation and GDP per capita did not seem to have much influence on credit rating among institutional owners. These were external variables that were related to the country and not to the particular organisations.

Table 4 compares Pearson's and Spearman's correlation matrix of variables related used in the study to see how they are related. The Pearson's parametric correlation coefficients are presented on the upper right and the Spearman's non-paramedic correlation coefficients are presented on the left side. This makes it possible to tell whether the correlation between variables is significant or not. A comparison of the relations between the Pearson and Spearman correlation matrix shows whether the variables are significant and whether they have a significant influence on credit ratings in terms of institutional ownership. 
Table 4. Pearson's and Spearman's correlation matrices of the variables

\begin{tabular}{|c|c|c|c|c|c|c|c|c|c|c|c|c|c|}
\hline Variable & IO & $S G$ & $F S$ & $A C N O$ & $\begin{array}{l}C G C \\
N O\end{array}$ & $S M C$ & $\begin{array}{l}\text { CORR } \\
\text { IDX }\end{array}$ & $I N F L$ & $P O P$ & $L V G$ & $A N G$ & $G D P C$ & POWD \\
\hline$I O$ & 1 & $.093^{* *}$ & $-.189^{* * *}$ & -.307 & .035 & .029 & $.106^{* * *}$ & $.109^{* * *}$ & -.028 & .036 & $.209^{* * *}$ & .042 & $-.138^{* * *}$ \\
\hline$F S$ & $-.233^{* * *}$ & $-.116^{* * *}$ & 1 & $.324^{* * *}$ & $.287^{* * *}$ & $.320^{* * *}$ & -.001 & -.010 & $.278^{* * *}$ & $.214^{* * *}$ & $-.148^{* * *}$ & -.046 & $.200^{* * *}$ \\
\hline$A C N O$ & -.388 & $-.112^{* * *}$ & $.319^{* * *}$ & 1 & $.213^{* * *}$ & $.247^{* * *}$ & $.197^{* * *}$ & -.041 & $.185^{* * *}$ & $.195^{* * *}$ & -.013 & .047 & -.021 \\
\hline$S M C$ & .038 & $-.155^{* * *}$ & $.269^{* * *}$ & $.330^{* * *}$ & $.186^{* * *}$ & 1 & $.271^{* * *}$ & $.165^{* * *}$ & $.784^{* * *}$ & -.002 & $.097^{* * *}$ & $.113^{* * *}$ & $-.175^{* * *}$ \\
\hline $\begin{array}{l}\text { CORR } \\
\text { IDX }\end{array}$ & $.093^{*}$ & -.039 & $-.060^{*}$ & $.129^{* * *}$ & $.353^{* * *}$ & $.271^{* * *}$ & 1 & $.055^{*}$ & -.016 & $-.184^{* * *}$ & $.517^{* * *}$ & $.655^{* * *}$ & $-.430^{* * *}$ \\
\hline$I N F L$ & $.112^{* * *}$ & $.194^{* * *}$ & -.032 & -.047 & $.131^{* * *}$ & $.165^{* * *}$ & $.106^{* * *}$ & 1 & .001 & -.002 & $.295^{* * *}$ & .040 & $-.176^{* * *}$ \\
\hline$G D P C$ & $.122^{* * *}$ & $.055^{*}$ & $-.068^{* *}$ & .047 & $.285^{* * *}$ & $.113^{* * *}$ & $.668^{* * *}$ & .040 & $.097^{* * *}$ & $-.216^{* * *}$ & $.680^{* * *}$ & 1 & $-.571^{* * *}$ \\
\hline POWD & $-.166^{* * *}$ & $-.088^{* * *}$ & $.194^{* * *}$ & -.021 & $-.362^{* *}$ & $-.430^{* * *}$ & $-.524^{* * *}$ & $-.176^{* * *}$ & $.067^{* *}$ & $.079^{* * *}$ & $-.726^{* * *}$ & $-.571^{* * *}$ & 1 \\
\hline
\end{tabular}

Notes: the upper right half of the table shows Pearson's parametric correlation coefficients, whereas the bottom left half of the table contains Spearman's non-parametric correlation coefficients. ${ }^{* *}$, and $*$ denote correlation is significant at the $1 \%$, and $5 \%$ level, respectively (two-tailed tests). Variables are defined as follows: Credit Rating (RA S\&P), Institutional Ownership (IO), Stock Market Capitalisation (SMC), Corruption Index (CORR IDX), Inflation (INFL), GDP per Capita (GDPC), Population (POP), Power Distance (POWD), Corporate Governance Committee No. (CGC NO), Audit Committee No. (AC), Firm Size (FS), Sales Growth (SG), Leverage (LVG).

For example, when we look at the relationship between institutional ownership and sales growth, we can see that Institutional ownership is correlated to sales growth at (.060), but a positive and significant relationship to sales growth to $(5 \%)$ at (.093). While one relationship is positive but not a significant, the other is positive and significance at (5\%). Institutional ownership has negative and significant relationship with firm size at (-.233) to $(1 \%)$ and at (-.189), also to (1\%).

Institutional ownership has a negative relationship to number of audit committees at (-.388) and at (-.307). These are not a significant relationships. Institutional ownership has a positive correlation to corporate governance committees at (.054) and (.035). These relationships are not significant. In terms of stock market capitalism, institutional ownership has a positive and not significant relationship with this variable at (.038) and (.029).

Institutional ownership showed correlation to corruption index at (.093) significant to $10 \%$ and significant to (.106) to (1\%). What this shows is that there is a definite significant relationship between institutional ownership and corruption in terms of credit rating. Similarly, inflation does have an influence on institutional ownership, with the correlation between institutional ownership and inflation being (.112) at (1\%) and at (.109) at (1\%).

Institutional relationship has a negative significant relationship to population at (-.080) to $(5 \%)$ and to $(-.028)$. In terms of leverage, institutional ownership has a positive relationship with this variable at (.007) and (.036), but the relationship though positive is not significant.

In terms of Anglo countries, there is a positive and significant relationship to (.253) and (.209) at (1\%) of significance, showing that there is a greater influence on institutional ownership in Anglo American companies.

Institutional ownership is positively and significantly related to GDP per capita at (.122) at (1\%) of significance, but at (.042). Therefore, in some instances, this relationship is significant, while in other cases, it is not significant.

In terms of power distance, institutional ownership was seen to have a negative and significant correlation at $1 \%$ at (-.166) and at (-.138).

\subsection{Regression Analysis}

Table 5 presents the statistics used in analysing and discussing corporate governance and its relation to credit 
rating. Institutional ownership is used to represent corporate governance. In Table 5, OLS Regression Results of Ownership Structure on Credit Rating (dependent variable), the F-Value is (11.901***), indicating that the model is positive and significant at $1 \%$. This model is a fit in predicting the relationships. The Adjusted $\mathrm{R}^{2} \%$ at $29.1 \%$ shows how the independent variable, the ownership structure and the control variables, will interpret the dependent variable, by $\mathrm{R}^{2} \%$. This suggests that any change in the independent and control variables will lead to a change in the dependent variable by $\mathrm{R}^{2}$.

The significant findings in Table 5 are institutional ownership, at $\left(4.662^{* * *}\right)$, which is significant at $(1 \%)$ and negative. The hypothesis that looks at institutional ownership and credit ratings is H1, which states that "there is no statistically significant relationship between institutional ownership and credit rating". The findings in Table 5 reveal a strong significant negative relation.

This suggests that institutional owners have a negative impact on credit rating for the period; the results show a significant relationship at $\left(4.662^{* * *}\right)$, significant at $1 \%$. However, earlier findings have arrived at mixed findings. For example, it has been pointed out that large institutional owners are more likely to have higher bond ratings, but that their bond yields are lower (Bhojraj and Sengupta, 2003). It was also suggested in some studies that institutional owners were more likely to invest in forms that already had high bond ratings and lower yields (Bhojraj and Sengupta, 2003). Therefore, it was suggested that institutional owners either invested in firms that had high bond ratings or else they were able to generate these high bond ratings. On the other hand, it was also suggested that the argument could be made for the case that institutional owners also had low bond ratings and higher yields (Bhojraj and Sengupta, 2003).

The explanation that could be given for these different results can be based on the theories that are used to explain the relationship. Agency theory holds that there is a conflict between owners and managers, with agents playing a monitoring role in ensuring that owners to do not take advantage of the situation and look after their own interests rather than the interests of the shareholders. Therefore, some see institutional owners are seen as playing a monitoring role. On the other hand, some may argue that institutional powers are managers that look after their own interests. Depending on which perspective is taken, institutional owners can be seen as either contributing to more or less monitoring of management. If they are seen as serving in a monitoring role, they could be seen as having a positive effect on credit ratings (Bhojraj and Sengupta, 2003).

The other theory that can be used is legitimacy theory which is based on the understanding that firms that have many institutional owners may invest in companies that have low bond yields (Elbannan, 2009). When there are too many institutional owners in a company, investors would very likely see this as a poor investment opportunity. Therefore, credit rating would very likely be poor.

Our findings confirm earlier work; we show that despite the investment choices of institutional owners, they have an impact on firm performance. Institutional owners are shown to invest in firms with higher bond ratings and lower bond ratings, consequently having both higher and lower bond yields. This also means that institutional owners influence bond ratings as well as bond yields. As a result, institutional owners not only influence, but themselves are influenced by, bond ratings and yields. Therefore, the findings support previous studies showing that institutional owners are significant (Bhojraj and Sengupta, 2003).

Table 5. OLS Regression Results of Ownership Structure \& Board Structure on Credit Rating (Dependent Variable)

\begin{tabular}{|c|c|c|c|c|c|c|}
\hline & $\begin{array}{l}\text { All firm } \\
\text { years }\end{array}$ & 2010 & 2011 & 2012 & 2013 & 2014 \\
\hline Adjusted $R^{2}$ & .291 & .303 & .281 & .286 & .278 & .297 \\
\hline Standard Error & 2.439 & 2.509 & 2.407 & 2.424 & 2.475 & 2.447 \\
\hline Durbin- Watson & .614 & 2.432 & 2.351 & 2.202 & 2.162 & 2.361 \\
\hline F-Value & $11.901 * * *$ & $3.910 * * *$ & $3.672 * * *$ & $3.736 * * *$ & $3.752 * * *$ & $3.926 * * *$ \\
\hline No. of Observations & 452 & 87 & 89 & 89 & 93 & 90 \\
\hline Constant & .984 & -1.580 & .447 & -.493 & 1.101 & 1.630 \\
\hline \multicolumn{7}{|l|}{ Independent Variables } \\
\hline Institutional Ownership & $-4.662 * * *$ & $-2.830 * * *$ & $-1.669 * *$ & -1.318 & $-2.085^{* * *}$ & $-2.316^{* * *}$ \\
\hline \multicolumn{7}{|l|}{ Control Variables } \\
\hline Firm Size & $8.017 * * *$ & $3.245 * * *$ & $3.758 * * *$ & $3.786 * * *$ & $3.534 * * *$ & $3.433 * * *$ \\
\hline Sales Growth & $-1.824 *$ & $-1.673 *$ & -1.111 & .327 & -1.316 & -.410 \\
\hline
\end{tabular}




\begin{tabular}{|c|c|c|c|c|c|c|}
\hline Audit Committee No. & .844 & .095 & .753 & .081 & .108 & .213 \\
\hline Corporate Governance & -.909 & .806 & .329 & .631 & -.455 & -.237 \\
\hline \multicolumn{7}{|l|}{ Committee No. } \\
\hline Leverage & $-5.443 * * *$ & $-2.462 * *$ & $-2.527 * *$ & $-1.668 *$ & $-2.078 * *$ & $-2.230 * * *$ \\
\hline Market & -.900 & $2.515^{* *}$ & 1.195 & $1.869^{*}$ & -.470 & $-2.728 * * *$ \\
\hline \multicolumn{7}{|l|}{ Capitalisation } \\
\hline Corruption Index & $1.928 *$ & $-1.916 * *$ & -1.012 & $-2.350 * *$ & 1.282 & 1.138 \\
\hline Inflation & -1.221 & $-2.864 * * *$ & $-2.850 * * *$ & $-3.095 * * *$ & -.421 & -.967 \\
\hline GDP Per Capita & -.207 & 1.482 & -.263 & .948 & -.940 & -.967 \\
\hline Population & $1.983 * *$ & $-2.297 * * *$ & -1.107 & $-1.771 *$ & .823 & $3.164 * * *$ \\
\hline Power Distance & $.935^{*}$ & -.326 & -.045 & -.890 & .507 & $1.780 *$ \\
\hline Anglo American & $1.915^{*}$ & $2.065^{* * *}$ & $2.357 * * *$ & .906 & 1.462 & 1.478 \\
\hline 2010 & .317 & - & - & - & - & - \\
\hline 2011 & .712 & - & - & - & - & - \\
\hline 2012 & .033 & - & - & - & - & - \\
\hline 2013 & -.246 & - & - & - & - & - \\
\hline
\end{tabular}

Notes: coefficients are in front of parenthesis. $* * *, * *$ and $*$ denote p-value is significant at the $1 \%, 5 \%$ and $10 \%$ level, respectively. Also, year 2013 are excluded from the regression analyses. It is used as base year, respectively, for purposes of comparison.

In the regression shown in Table 5 above, there is a strong relationship shown between institutional ownership and credit rating. This relationship is negative and significant at (-4.662), indicating that the more institutional ownership that is in a company the lower will be the credit rating for that firm. Among the companies that were included in this study, it was shown that in many of those companies that had a greater degree of institutional ownership, there was also the tendency for them to have lower credit ratings. In terms of the control variables, we can see significant on firm size $\left(8.017^{* * *}\right)$ and positive. Similarly, in terms of population, the relationship between population and credit ratings was positive and significant. However, sales growth at $(-1.824)$ was negative, with leverage at (-5.443) being both significant and negative. The findings also revealed that Anglo American with $\left(1.915^{*}\right)$ was positive, showing that that Anglo American countries tended to be more positive than the continental countries in terms of the positive negative influence that institutional owners had on credit ratings. The explanation here is based on the particular approach taken by the models. The Anglo-American model holds that the director of organisations has a fiduciary duty to its shareholders to maximise return on their shareholder value. According to Gamble and Kelly (2001), the shareholders are the ones that are thought to have the right to the greatest returns because they are the ones that take the greatest risks. These shareholders are seen as the ones that are the major owners of the organisations (Gamble and Kelly, 2001). It is this reasoning that sees the Anglo-American model as showing a positive relationship between institutional owners and credit ratings.

\subsection{Further Analysis}

In carrying out a comparison of the regression results over institutional ownership on credit rating over all the years, one would see that in 2010 , there was a negative and significant relationship of $(-2,830)$. In 2011 , that figure decline to (-1.669) and was both negative and significant. In 2012, it fell even more to (- 1.318), but while negative, it was not significant. This meant that companies with institutional ownership did not exert as strong a negative impact as in earlier years. However, in 2013 and 2014, these figures increased markedly to (-2.085) and $(-2.316)$ respectively and both were negative as well as significant. The figure for all firm years was $(-4.622)$, negative and significant. The trend has been over the five years one in which institutional ownership had a negative influence on credit ratings.

In comparing the years for firm size, one can see that over the five years from 2010 to 2014, there has been slight fluctuations of the influence of firm size on credit rating, with the all firm years being positive and significant. The implication here is that over this period, the size of the firm was important in influencing credit ratings among firms with institutional ownership.

Leverage over the years showed that companies with a high ratio of total debt to total assets tended to have a negative influence on credit rating among companies with institutional ownership. There were fluctuation among the years, going from $(-2.462)$ to $(-2.527)$, to $(-1.668)$, to $(-2.078)$, to $(-2.230)$ from 2010 to 2014 , and with leverage for all years being (-5.443), all negative and all significant. What this indicates is that companies with institutional ownership tended to be heavily encumbered with debt and to be poor on credit rating.

Stock market capitalisation fluctuated over this period, going from a positive and significant figure of (2.515) in 
2010 to a negative and significant figure of $(-2.728)$ in 2014, leading to a stock market capitalisation for all firm years of (-.900). Credit rating therefore showed fluctuations over this period based on stock market capitalisation.

The Anglo American variable was positive throughout the period from 2010 to 2014, but was significant for 2010 and 2011, at (2.065) and (2.357). The figure for all firm years in was (1.915) and was significant, but for the years 2010 to 2013, the all years figures were (.317), (.712), (.033), and (-.246) from 2010 to 2013. This reveals that institutional ownership had a mostly positive effect on credit rating among Anglo American companies. Gamble and Kelly (2001) support this finding. Using the agency theory, this finding was also supported (Ashbaugh-Skaife et al., 2006).

\section{Conclusions}

This study has accomplished what it set out to do. It set out to investigate the possible impact of institutional ownership on credit rating and to contribute to the extant literature on the subject. It took a multitheoretical approach using agency and legitimacy theories, rather than just using a single theory. More than that, unlike previous studies that looked at credit ratings within one country, this study examined credit ratings among several countries, but it went further and looked at countries from two different traditions, namely, Anglo American represented by US, UK, Australia, Canada and Ireland, and the Continental European tradition, including Germany, France, Italy, Spain and Japan.

Using a total of 200 firms form these varied backgrounds, this study looked at the relationship between institutional ownership and credit rating, started with the null hypothesis that there is no statistically significant relationship between the two variables. Besides looking at country-wide differences based on different traditions, this study also looked at firm-level control variables, such as firm size, growth, profitability and leverage within the multitheoretical framework.

The findings in this study supported the hypothesis showing that there was a strong relation between institutional ownership and credit rating. More specifically, it follows that institutional owners, who are responsible for the investments of other people, tend to be particularly concerned about their fiduciary responsibility towards their investors. It follows that these institutional owners therefore choose companies that have high bond earnings, and whose bond yields are lower. It follows that these institutional owners are acting as good agents and as engaging in effecting monitoring of management. Applying the agency theory to this situation, it would follow that this monitoring of management represents good governance and would of necessity show that the shareholders' rights are being protected. This therefore justifies higher bond yields.

However, it was shown that there are some institutional owners that invest in companies with high bond yields and higher bond earnings. But according to Bhojraj and Sengupta (2003), while some institutional owners invest in companies with high yields and high earnings, some Institutional owners are also influenced by the high bond yields and high bond ratings. But as noted earlier, legitimacy theory shows that there is also a negative relationship between institutional ownership and credit rating. These findings are based on the findings of earlier studies which showed that agency theory often comes out with different findings, because owners and managers often seem to have different interests, while at the same time many managers serve their constituents, the shareholders, very well. Legitimacy theory shows institutional legitimacy, or the degree to which firms confirm to established practices of other similar social organisations. But legitimacy theory also supports some of the practices that agency theory supports, with agency theory seeming to work best in firms that follow the Anglo American tradition or shareholding model, and legitimacy theory seeming to work best in firms that follow the Continental European tradition or stakeholding model.

While other studies have investigated the impact of corporate governance on single countries, this study has looked at the different countries, therefore allowing for some generalisability around findings. The study has therefore allowed to show how legal, financial and other country characteristics have an influence on corporate governance and on its influence on credit rating through the proxy of institutional ownership. Seeing that some countries adhere more to the agency theory as opposed to the legitimacy theory, this comparative study has allowed to show how corporate governance addresses agency and legitimacy issues and how the countries with different traditions fare when compared in terms of institutional ownership. This is important for it allows investors to know what to look for when making decisions about investing in firms in different countries.

\section{References}

Abdullah, H., \& Valentine, B. (2009). Fundamentals and Ethics Theories of Corporate Governance. Middle Eastern Finance and Economics, 4, 88-96. 
Aguilera, R. V., \& Cuervo-Cazurra, A. (2009). Codes of good governance, Corporate Governance: An International Review, 17(3), 376-387.

Aguilera, R. V., \& Jackson, G. (2010). Comparative and International Corporate Governance. The Academy of Management Annals, 4(1), 485-556. https://doi.org/10.1080/19416520.2010.495525

Ahmad, T., Rashmi, P., Bakshi, P., \& Saha, A. (2009). An assessment of role of credit ratings agencies in the corporate governance process: The case for including internal contracts in the formal rating assessment. Social Science Research Network. Retrieved from http://papers.ssrn.com/so13/papers.cfm?abstract_id=1486679

Alshammari, M. (2015). Corporate Social Responsibility and Firm Performance: The Moderating role of reputation and institutional investors. International Journal of Business and Management, 10(6), 15. https://doi.org/10.5539/ijbm.v10n6p15

Anderson, R. C., Mansi, S. A., \& Reeb, D. M. (2003). Founding family ownership and the agency cost of debt. Journal of Financial Economics, 68(2), 263-285. https://doi.org/10.1016/S0304-405X(03)00067-9

Ashbaugh-Skaife, H., Collins, D. W., \& LaFond, R. (2004).Corporate governance and the cost of equity capital. Working paper, University of Wisconsin, and University of Iowa.

Ashbaugh-Skaife, H., Collins, D. W., \& LaFond, R. (2006). The effects of corporate governance on firms' credit ratings. Journal of Accounting and Economics, 42(1), 203-243. https://doi.org/10.1016/j.jacceco.2006.02.003

Avramov, D., Chordia, T., Jostova, G., \& Philipov, A. (2009). Dispersion in analysts' earnings forecasts and credit rating. Journal of Financial Economics, 91(1), 83-101. https://doi.org/10.1016/j.jfineco.2008.02.005

Barinov, A. (2017). Institutional ownership and aggregate volatility risk. Journal of Empirical Finance, 40, 20-38. https://doi.org/10.1016/j.jempfin.2016.11.003

Beasley, M. S. (1996). An empirical analysis of the relation between the board of director composition and financial statement fraud. Accounting Review, 71(4), 443-465.

Beiner, S., Drobetz, W., Schmid, M. M., \& Zimmermann, H. (2006).An integrated framework of corporate governance and firm valuation. European Financial Management, 12(2), 249-283. https://doi.org/10.1111/j.1354-7798.2006.00318.x

Bhojraj, S.,\& Sengupta, P. (2003). Effect of corporate governance on bond ratings and yields: The role of institutional investors and outside directors. The Journal of Business, 76(3), 455-475. https://doi.org/10.1086/344114

Chang, K., Kang, E., \& Li, Y. (2016). Effect of institutional ownership on dividends: An agency-theory-based analysis. Journal of Business Research, 69(7), 2551-2559. https://doi.org/10.1016/j.jbusres.2015.10.088

Chen, J. C., \& Roberts, R. W. (2010). Toward a more coherent understanding of the organisation-society relationship: A theoretical consideration for social and environmental accounting research. Journal of Business Ethics, 97(4), 651-665. https://doi.org/10.1007/s10551-010-0531-0

Chen, K. C., Chen, Z., \& Wei, K. C. (2009). Legal protection of investors, corporate governance, and the cost of $\begin{array}{lllll}\text { equity capital. Journal of } & \text { Corporate }\end{array}$ https://doi.org/10.1016/j.jcorpfin.2009.01.001

Cheng, M., \& Subramanyam, K. R. (2008). Analyst following and credit ratings. Contemporary Accounting Research, 25(4), 1007-1044. https://doi.org/10.1506/car.25.4.3

Daniel, S. J., Cieslewicz, J. K., \& Pourjalali, H. (2012). The impact of national economic culture and country-level institutional environment on corporate governance practices. Management International Review, 52(3), 365-394. https://doi.org/10.1007/s11575-011-0108-x

Dasilas, A., \& Papasyriopoulos, N. (2015). Corporate governance, credit ratings and the capital structure of Greek SME and large listed firms. Small Business Economics, 45(1), 215-244. https://doi.org/10.1007/s11187-015-9648-y

Deegan, C., \& Bloomquist, C. (2006). Stakeholder influence on corporate reporting: An exploration between world wide fund for nature and Australia minerals industry. Accounting Organisations and Society, 3(4/5), 343-372. https://doi.org/10.1016/j.aos.2005.04.001

Del Guercio, D. (1996). The distorting effect of the prudent-man laws on institutional equity investments. 
Journal of Financial Economics, 40(1), 31-62. https://doi.org/10.1016/0304-405X(95)00841-2

Djankov, S., Lopez, R., La Porta, F., \& Shleifer, A. (2008). The law and economics of self-dealing. Journal of Financial Economics, 88(3), 430-45. https://doi.org/10.1016/j.jfineco.2007.02.007

Driss, H., Massoud, N., \& Roberts, G. S. (2016). Are credit rating agencies still relevant? Evidence on certification from Moody's credit watches. Journal of Corporate Finance. https://doi.org/10.1016/j.jcorpfin.2016.08.003

Elbannan, M. A. (2009). Quality of internal control over financial reporting, corporate governance and credit ratings. International Journal of Disclosure and Governance, 6(2), 127-149. https://doi.org/10.1057/jdg.2008.32

Farooqi, J., Jory, S., \& Ngo, T. (2017). Institutional investors' activism and credit ratings. Journal of Economics and Finance, 4l(1), 51-77. https://doi.org/10.1007/s12197-015-9332-8

Fitch Ratings. (2004). Credit policy special report, evaluating corporate governance: The bondholders' perspective. New York.

Forbes. (2000). FORBES Global 2000 Leading Companies. Retrieved from http://www.forbes.com/global2000

Gamble, A., \& Kelly, G. (2001). Shareholder value and the stakeholder debate in the UK. Corporate Governance: An International Perspective, 9(2), 110-117. https://doi.org/10.1111/1467-8683.00235

Garmaise, M.J \& Liu, J. (2005).Corruption, firm governance, and the cost of capital. AFA 2005 Philadelphia Meetings Paper. http://dx.doi.org/10.2139/ssm.644017

Gillan, S. L., \& Starks, L. T. (2000). Corporate governance proposals and shareholder activism: The role of institutional investors. Journal of Financial Economics, 57(2), 275-305. https://doi.org/10.1016/S0304-405X(00)00058-1

Gillan, S., \& Starks, L. T. (2003). Corporate governance, corporate ownership, and the role of institutional investors: A global perspective.

Gompers, P., Ishii, J., \& Metrick, A. (2003).Corporate governance and equity prices. The Quarterly Journal of Economics, 118(1), 107-156. https://doi.org/10.1162/00335530360535162

Griffin, D., Guedhami, O., Kwok, C. C., Li, K., \& Shao, L. (2014). National Culture, Corporate Governance Practices, and Firm Performance. Corporate Governance Practices, and Firm Performance (February 23, 2014), 1-62. https://doi.org/10.2139/ssrn.2400078

Grinstein, Y., \& Michaely, R. (2005). Institutional holdings and payout policy. The Journal of Finance, 60(3), 1389-1426. https://doi.org/10.1111/j.1540-6261.2005.00765.x

Hail, L., \& Leuz, C. (2006). International differences in the cost of equity capital: Do legal institutions and securities regulation matter? Journal of Accounting Research, 44(3), 485-531. https://doi.org/10.1111/j.1475-679X.2006.00209.x

Han, B., Subrahmanyam, A., \& Zhou, Y. (2017). The term structure of credit spreads, firm fundamentals, and expected stock returns. Journal of Financial Economics. https://doi.org/10.1016/j.jfineco.2017.01.002

Hansson, M., Liljeblom, E., \&Martikainen, M. (2011).Corporate governance and profitability in family SMEs.The European Journal of Finance, 17(5-6), 391-408. https://doi.org/10.1080/1351847X.2010.543842

Hofstede, G. (1984). Cultural dimensions in management and planning. Asia Pacific. Journal of Management, January, 81-90. https://doi.org/10.1007/BF01733682

Hutchinson, M., Seamer, M., \& Chapple, L. E. (2015). Institutional investors, risk/performance and corporate governance. The International Journal of Accounting, 50(1), 31-52. https://doi.org/10.1016/j.intacc.2014.12.004

Jiraporn, P., Kim, J. C., Kim, Y. S., \& Kitsabunnarat, P. (2012). Capital structure and corporate governance quality: Evidence from the Institutional Shareholder Services (ISS). International Review of Economics \& Finance, 22(1), 208-221. https://doi.org/10.1016/j.iref.2011.10.014

Jorion, P., \& Zhang, G. (2010). Information transfer effects of bond rating downgrades. Financial Review, 45(3), 683-706. https://doi.org/10.1111/j.1540-6288.2010.00266.x

Kirkpatrick, G. (2009). Corporate Governance Lessons from the Financial Crisis. OECD Journal: Financial Market Trends, 2009(1), 61-87. https://doi.org/10.1787/fmt-v2009-art3-en 
Krenn, M. (2014). Decoupling as a sustainable firm response to pressures for convergence and divergence in corporate governance: The case of codes of good corporate governance. Journal of Management Policy and Practice, 15(4).

Kumar, P., \& Zattoni, A. (2013).Corporate governance, board of directors, and firm performance. Corporate Governance: An International Review, 21(4), 311-313. https://doi.org/10.1111/corg.12032

La Porta, R., Lopez-De-Silanes, F., Shleifer, A., \& Vishny, R. (2002). Investor protection and corporate valuation. The Journal of Finance, 5(3), 1147-1170. https://doi.org/10.1111/1540-6261.00457

Lai, J. H., \& Chen, L. Y. (2014). The valuation effect of corporate governance on stakeholder wealth: Evidence from strategic alliances. International Review of Economics \& Finance, 32, 117-132. https://doi.org/10.1016/j.iref.2014.01.010

Letza, S., Sun, X., \& Kirkbride, J. (2004). Shareholding versus stakeholding: A critical review of corporate governance. Corporate Governance: An International Review, 12(3), 242-262. https://doi.org/10.1111/j.1467-8683.2004.00367.x

Lin, Y. M., \& Shen, C. A. (2015).Family firms' credit rating, idiosyncratic risk, and earnings management. Journal of Business Research, 68(4), 872-877. https://doi.org/10.1016/j.jbusres.2014.11.044

Matthies, A. B. (2013). Empirical research on corporate credit-ratings: A Literature Review (No. 2013-003). SFB 649 Discussion Paper. Available at $h t t p: / / h d l . h a n d l e . n e t / 10419 / 79580$.

Ntim, C. G., Opong, K. K., \&Danbolt, J. (2012). The relative value relevance of shareholder versus stakeholder corporate governance disclosure policy reforms in South Africa. Corporate Governance: An International Review, 20(1), 84-105. https://doi.org/10.1111/j.1467-8683.2011.00891.x

OCED Survey. (2004). Corporate Governance: A survey of OECD countries. Retrieved from http://www.oecd.org/corporate/ca/corporategovernanceprinciples/21755678.pdf

OECD (2004). Principles of Corporate Governance. OECD. Retrieved from http://www.oecd.org/corporate/ca/corporategovernanceprinciples/31557724.pdf

OECD (2014). The 'Marshall Plan' speech at Harvard University on 5 June, 1947, quoted in OECD website at http://www.oecd.org

Radebaugh, L. H., Gray, S. J., \& Back, E. L. (2006). International accounting and multinational enterprises. Hamilton: Wiley. International Perspective, 5(1), 3-10.

Renders, A., Gaeremynck, A., \& Sercu, P. (2010). Corporate - governance ratings and company performance: A cross-European study. Corporate Governance: An International Review, 18(2), 87-106. https://doi.org/10.1111/j.1467-8683.2010.00791.x

Schain, J. P., \& Stiebale, J. (2016). Innovation, institutional ownership, and financial constraints (No. 219). DICE Discussion Paper.

Shleifer, A., \& Vishny, R. W. (1997).A survey of corporate governance. The Journal of Finance, 52(2), 737-783. https://doi.org/10.1111/j.1540-6261.1997.tb04820.x

Standard. \& Poor's, (2002). Standard \& Poor's corporate governance scores: criteria, methodology and definitions. New York: McGraw-Hill Companies, Inc.

Sternberg, E. (1997). The defects of stakeholder theory. Corporate Governance: Scholarly Research and Theory Papers, 5(1), 3-10. https://doi.org/10.1111/1467-8683.00034

Switzer, L. N., \& Wang, J. (2013). Default risk estimation, bank credit risk, and corporate governance. Financial Markets, Institutions \& Instruments, 22(2), 91-112. https://doi.org/10.1111/fmii.12005

Tran, D. H. (2014). Multiple corporate governance attributes and the cost of capital-Evidence from Germany. The British Accounting Review, 46, 179-197. https://doi.org/10.1016/j.bar.2014.02.003

Vinten, G. (2001). Shareholder versus Stakeholder-is there a Governance Dilemma? Corporate Governance: An International Perspective, 9(1), 36-47. https://doi.org/10.1111/1467-8683.00224

Wang, A. W., \& Zhang, G. (2009). Institutional ownership and credit spreads: An information asymmetry perspective. Journal of Empirical Finance, 16(4), 597-612. https://doi.org/10.1016/j.jempfin.2009.04.002

Weimer, J., \& Pape, J. C. (1999). A Taxonomy of systems of corporate governance. Corporate Governance: An International Perspective, 7(2), 152-166. https://doi.org/10.1111/1467-8683.00143 
Weir, C., \& Laing, D. (2000). The performance-governance relationship: The effects of Cadbury compliance on UK Quoted companies. Journal of Management and Governance, 4(4), 265-282. https://doi.org/10.1023/A:1009950903720

Weir, C., Laing, D., \& McKnight, P. J. (2002). Internal and external governance mechanisms: their impact on the performance of large UK public companies. Journal of Business Finance \& Accounting, 29(5-6), 579-611. https://doi.org/10.1111/1468-5957.00444

Wright, P., Ferris, S. P., Sarin, A., \& Awasthi, V. (1996). Impact of corporate insider, blockholder, and institutional equity ownership on firm risk taking. Academy of Management Journal, 39(2), 441-458. https://doi.org/10.2307/256787

Yermack, D. (1996). Higher market valuation of companies with a small board of directors. Journal of Financial Economics, 40(2), 1F85-211. https://doi.org/10.1016/0304-405X(95)00844-5

Zattoni, A., \& Cuomo, F. (2008). Why adopt codes of good governance? A comparison of institutional and efficiency perspectives. Corporate Governance: An International Review, 16(1), 1-15. https://doi.org/10.1111/j.1467-8683.2008.00661.x

\section{Copyrights}

Copyright for this article is retained by the author(s), with first publication rights granted to the journal.

This is an open-access article distributed under the terms and conditions of the Creative Commons Attribution license (http://creativecommons.org/licenses/by/4.0/). 